UC Riverside plant pathologist Donald Cooksey also emphasized the variety of genetic strains of Pierce's disease. Some strains of $X$. fastidiosa can cause disease on grapes, almonds and alfalfa, while others attack citrus, coffee and oleander specifically. Xylella is a specialized pathogen, growing only in the plant xylem and insect mouthparts. Strategies to prevent disease include techniques to prevent establishment of Xylella in the sharpshooter mouthparts and the use of harmless, naturally occurring endophytic bacteria to compete with Xylella for colonization of grapevines.

Damage to grapevines in the Napa and Sonoma valleys tends to be concentrated at the edges of vineyards, UC Berkeley entomologist Alexander Purcell told the workshop. With the introduction of GWSS, there could be transmission from vine to vine, and the possibility of an exponential growth in numbers of infected plants.

Sponsors of the conference included UC agricultural departments and centers, UC Cooperative Extension, the North Coast Pierce's Disease Task Force, and a variety of vintners and agricultural suppliers.

- Michael Barnes

\title{
Central Valley growers pulling grapevines
}

$\mathrm{F}$ aced with a grape glut and depressed prices, 1 grape growers in the Central Valley have pulled out more than 50,000 acres of vines since 1999.

"Whenever there's a glut, the Central Valley always gets hit the hardest," UC viticulture advisor Stephen Vasquez says, "because it has more uncontracted acreage and its climate is not conducive to higher-end grapes."

The 8-county region's total grape acreage peaked at nearly 600,000 acres in 1999 . The removed acreage, taken out between 1999 and April 2003, represents more than 400,000 tons of production, says

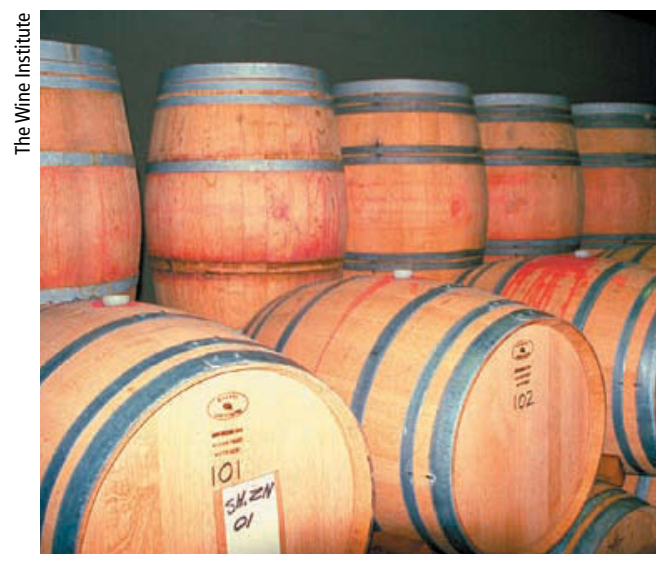

Grape production was up $12.5 \%$ in 2002 , but prices received by growers were $17 \%$ lower. industry analyst Tony

Correia.

The estimates are based on permits approved by the Regional Air Quality Control Board, which bans the burning of treated wood used for vineyard stakes and requires the careful separation of removed vines and stakes. With subsequent removal costs running about $\$ 400$ per acre, some growers are simply abandoning their vines, Correia says. "If it was easier and cheaper, we would be seeing even more removals."

Nearly three-quarters of the acreage uprooted is in Fresno, Kern and Tulare counties, primarily old vineyards or those without grape contracts, Correia reported at the May 30 Vineyard Economics Seminar in Napa. The varieties being pulled are mostly wine varieties, plus older Thompson Seedless raisins and table grapes.

"Many of the growers are converting to citrus or almonds," Vasquez notes.

Behind dairy, grapes are the state's second largest agricultural sector, worth $\$ 2.6$ billion in 2002. According to a March 2003 California Department of Food and Agriculture report, California crushed 3.8 million tons of grapes (including wine, raisins and table grapes) in 2002, up $12.5 \%$ from 2001, while growers received average prices $17 \%$ lower than the previous year. Growers without contracts for their grapes faced the lowest spot-market prices in decades.

The wine industry has been hit by overplanting and reduced consumption due to a weakened economy. In addition, there has been an influx of inexpensive imports from Chile, Australia and South Africa. As a result, the industry has fragmented into distinct price and quality sectors, from ultrapremium to jug wines (see page 71). Indeed, Napa Valley growers earned nearly $\$ 3,000$ per ton for their high-value grapes in 2002, while Fresno-area growers took in $\$ 136$ per ton for lesser-quality varieties, CDFA reported.

Despite recent turmoil, the industry appears to have turned a corner, says David Freed of the Universal Capital Corporation (UCC) Group, which conducts an annual economics survey of the wine industry. Freed says that the outlook for "workhorse" varieties such as Chardonnay is improving. "People tend to talk red and drink white," Freed says.

UC viticulture advisor Ed Weber said that a silver lining of recent wine industry trends - for consumers, at least - may be the success of popular, very low-priced wines such as Charles Shaw, which is flying off the shelves for $\$ 1.99$ per bottle at Trader Joe's.

The overwhelming success of so-called "twobuck Chuck" - which has sold an unprecedented 5 to 6 million cases since its introduction in early 2001 - demonstrates the ability of the wine industry to develop new markets for lower-quality fruit, Weber says.

Furthermore, Vasquez says, "This is an opportunity for people who didn't drink wine before to try it, and possibly look into higher-priced wines." 